\title{
Porous carbon in catalytic transformation of cellulose
}

\author{
Xiaochen Zhao, Jinming Xu, Aiqin Wang, Tao Zhang * \\ State Key Laboratory of Catalysis, Dalian Institute of Chemical Physics, Chinese Academy of Sciences, Dalian 116023, Liaoning, China
}

\section{A R T I C L E I N F O}

Article history:

Received 29 May 2015

Accepted 28 June 2015

Published 20 September 2015

Keywords:

Biomass conversion

Catalysis

Porous carbon

Activated carbon

Mesoporous carbon

Cellulose

\begin{abstract}
A B S T R A C T
The application of porous carbon in catalytic transformation of cellulose has received considerable interest owing to increasing energy and environmental pressures. In this mini-review, we first outline the featured properties of porous carbon in catalytic cellulose transformation in terms of porosities and surface functionalities. An interconnected hierarchical structure and enrichment of mesopores are highly desired for reactant, intermediate, and product diffusion; while hydrophilic surfaces are favored in aqueous phase transformation and certain acidic oxygen functionalities play a role of acid sites as well as enhancing the adsorption of feedstock via 1,4-glycosidic bonds. We then summarize specific reactions in cellulose transformation in the order of hydrolysis and hydrolytic hydrogenation. In the hydrolysis of cellulose, porous carbon is generally used as a solid acid by taking advantage of its enriched oxygen functionalities, while in the hydrolytic hydrogenation, carbon serves as the support of bifunctional catalysts with active acidic sites. Finally, the synthesis and potential application of specific novel porous carbon materials, such as heteroatom-modified porous carbon and mesoporous carbon composites, are highlighted.
\end{abstract}

(C) 2015, Dalian Institute of Chemical Physics, Chinese Academy of Sciences. Published by Elsevier B.V. All rights reserved.

\section{Introduction}

Because biomass is the only renewable organic carbon resource in nature, its conversion into value-added products stimulates tremendous interest [1-4]. With particular regard to current energy and environmental pressures, catalytic biomass conversion offers many opportunities in energy substitution and chemical production, and is considered an efficient, environmental benign, and high atom economy "green" process. To avoid conflict between the food and fuel industries, inedible lignocellulose, which comprises cellulose, hemicellulose, and lignin, is broadly accepted as a biomass resource for the production of fuels and chemicals. In lignocellulose, cellulose $((40-50) w t . \%)$ acts like a scaffold to maintain the structural stability of plants; hemicellulose ((16-33) wt.\%) acts like a string that binds the cellulose fibers, and lignin ((15-30) wt.\%) acts like cement to harden the structure [5-7]. Of all these components, cellulose is the most abundant biomass with a huge global production of up to 70 billion tons/year [6]; its structure comprises numerous hydroxyl groups making it an ideal feedstock for the manufacture of industrially important products. Therefore, in this mini-review we have focused only on the catalytic transformation of cellulose; further information on the conversion of lignin and other feedstocks can be found in other recent publications $[8,9]$.

Owing to its abundant intra- and inter-molecular hydrogen bonds, cellulose is intrinsically resistant to the cleavage of its $\beta$-1,4-glycosidic bonds, and pretreatments to disassemble the supramolecular cellulose structure are usually required for the subsequent catalytic transformation process $[2,4,10]$. Even so, the diffusion of the degraded polymeric cellulose and its accessibility to active sites are still substantially conditioned by the

\footnotetext{
* Corresponding author. Tel: +86-411-84379015; Fax: +86-411-84685940; E-mail: taozhang@dicp.ac.cn This work was supported by the National Natural Science Foundation of China $(21303187,21403218,21176235)$. 
structure and porosity of the catalyst support. The sole presence of micropores imposes diffusion limitations and slow mass transport to and from active sites located within the micropores, which represents the major drawback in cellulose conversions by zeolites. Therefore, the design and application of hierarchical porous materials comprising meso- and micropores is highly desirable [10]. However, long-channeling pores are generally disfavored in biomass conversion owing to concerns about pore blockage and bulky molecule diffusion $[11,12]$. On the other hand, since the transformation of cellulose into fuels is an $0 / \mathrm{C}$ ratio reduction process, excess oxygen must be removed in the aqueous phase at high temperatures and/or high pressures, and hydrothermal stability is, therefore, another crucial requirement of the catalyst and its support $[2,4,10]$.

In view of its diversified porosity, high hydrothermal stability, and large surface area, activated carbon is considered one of the most promising candidates in catalytic cellulose transformation [2,13]. In addition, its tunable surface polarity and hydrophility/hydrophobicity, and its resistant to acidic and basic media endow carbon with unique advantages in both academic research and industrial applications. Furthermore, advances in nanocarbon technology have enabled the controllable tailoring of the pore structure and surface functionalities of porous carbon [14-16], and thus provided a possibility to clear the role porous carbon playing and allowed a rational design of new catalysts for cellulose transformation. To more clearly depict its function, we opt to highlight the properties of porous carbon first, and then to discuss most of the recently reported examples of catalytic cellulose transformation involving porous carbon. At the end of this paper, provisional conclusions and take-home messages will be provided.

\section{Properties of porous carbon in catalytic cellulose transformation}

\subsection{Porosities}

Porosity in activated carbon is created during the carbonization of an organic macromolecular precursor. The removal of small molecules brings distortions within the structure and hence forms micropores of $<2 \mathrm{~nm}$. Because the heat treatment temperature is usually below $1000{ }^{\circ} \mathrm{C}$, the graphitization level of activated carbon is relatively low. Although the porosity structure models are controversial [17], it is widely accepted that activated carbon comprises three pore categories with regard to size (macro-, meso-, and micropores), while micro-sized pores are dominant $\left(>0.2 \mathrm{~cm}^{3} / \mathrm{g}\right)$ and account for most of its internal surface area ( $\left.>400 \mathrm{~m}^{2} / \mathrm{g}\right)$. Therefore, diffusion limitation and accessibility to active sites become important issues when employing activated carbon as the catalyst support. A particular concern in liquid phase cellulose transformation, apart from the large size of the reactants, is that multilayer of solvent are found to form in the pores via sequential diffusion, and the accumulation of such solvents is considered to be the major cause of catalyst deactivation [18]. Activated carbon, which has much less uniformity of pore size and shape, is perhaps more easily blocked and more strongly affected by the diffusion limitations. Generally, pretreatment of activated carbon, such as by oxidation or sulfonation, can provide larger, more irregular pores, though the function of activation is usually claimed for surface chemistry modification.

With the development of material science, the concise control of meso-structure and morphology becomes possible. Typically, phenolic resin, furfural resin, glucose, and some biomass-derived precursors are able to act as the carbon source, and they endow the obtained mesoporous carbon a similar texture to that of activated carbon. A soft or hard templating strategy has been used to form mesopores of 2-10 nm diameter with ordered/disordered 2D/3D pore structures. Moreover, to optimize the mass transport network, macropore-sized templates have also been introduced to the synthesis system to obtain hierarchical structured porous carbon. In principle, a highly interconnected hierarchical structure will improve the diffusion of the reactant as well as its accessibility to active sites.

\subsection{Surface functionalities}

Cellulose transformation is a solid-solid interaction at the initial stages of the process, and adsorption of the feed cellulose and desorption of the product depend strongly on the hydro-

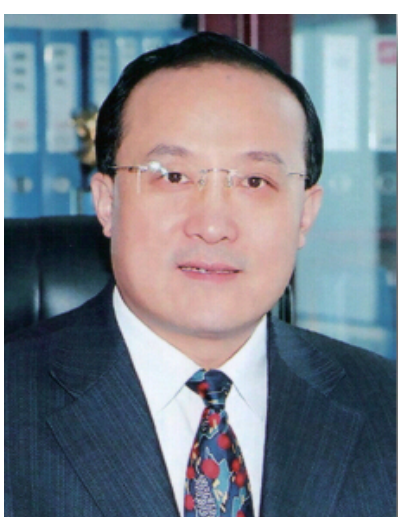

Tao Zhang (Dalian Institute of Chemical Physics, Chinese Academy of Science) received the Catalysis Award for Young Scientists in 2008, which was presented by The Catalysis Society of China. Professor Tao Zhang received his Ph.D. degree from Dalian Institute of Chemical Physics (DICP), Chinese Academy of Sciences, in 1989, and he joined the same institute and was promoted to full professor in 1995. He did postdoctoral research with Prof. Frank Berry at Birmingham University in 1990. Prof. Zhang was an invited professor at Univesity of Poitiers (France) in 2006-2007, and he has been a guest professor at University of Namur (Belgium) since 2011. He is currently the director of DICP (since 2007). Prof. Zhang has also received several research awards, including the Distinguished Award of Chinese Academy of Sciences (2010), Zhou Guangzhao Foundation Award for Applied Science (2009), National Award of Technology Invention (2008, 2006, 2005). He was selected as an academician of the Chinese Academy of Sciences. In the past decades, Prof. Zhang has successfully designed a great number of nano and subnano metallic catalysts for applications in energy conversion and environmental control. His research interests include (1) Design and synthesis of nano- and subnano catalytic materials; (2) utilization of biomass for production of chemicals. 
phobicity/hydrophilicity of the surface. During conversion to intermediates or to liquid fuels, the oxygen content of the cellulose, rich in hydrophilic components, will decrease and the hydrophobicity of the substrate will increase in successive steps.

Therefore, hydrophilic surfaces will benefit these transformation, as they facilitate both the adsorption of cellulose substrates and the desorption of less hydrophilic products [10].

Formed spontaneously by exposure to the atmosphere, the carbon surface contains a given number of oxygenated functions, similar to the way that heteroatoms appear in organic compounds. The presence of these functionalities endows the carbon surface, but not limited, with a hydrophilic character, which is beneficial to catalytic cellulose transformation. Moreover, a hydrophilic surface is more accessible to aqueous solutions of the metal precursor used in the impregnation process, enhancing the dispersion of metal on the carbon support and the subsequent catalytic activity [13].

In the transformation of cellulose, hydrolysis usually proceeds in the beginning to degrade cellulose into soluble saccharides, which includes two steps: $\mathrm{H}^{+}$attack of the $\beta$-1,4-glycosidic bonds in the crystalline cellulose to form water-soluble $\beta$-1,4-glucan, followed by hydrolysis of the $\beta$-1,4-glycosidic bonds in the $\beta$-1,4-glucan to form glucose. Therefore, a strong interaction between the solid acid and $\beta$-1,4-glucan is required because Brönsted acid sites cannot approach the cellulose surface without such an interaction. Rewarded by the abundant carboxyl, anhydride, hydroxyl, lactone, and lactol functionalities, amorphous carbon, on one hand, plays the role of solid Brönsted acid, and on the other hand, adsorbed considerable hydrophilic reactants (including cellulose, $\beta$-1,4-glucan, and water) on its surface, thereby playing a major role in solid-solid interaction at the interface. According to Hara's calculation, the apparent activation energy $\left(E_{\mathrm{a}}\right)$ for the hydrolysis of cellulose into glucose over carbon is much lower than that in the homogeneous acid system, and a distinct reaction route over carbon catalysts was suggested [19]. However, the authors preferred a two-step process in the hydrolysis of cellulose to explain the lower $E_{\mathrm{a}}$, including initial hydrolysis of cellulose into soluble saccharides in/by hot water, and further hydrolysis of the resulting soluble saccharides over carbon catalysts.

\section{Porous carbon in cellulose transformation}

\subsection{Hydrolysis}

As aforementioned, hydrolyzing cellulose into soluble saccharides is usually an entry point, as well as a rate-determining step in catalytic cellulose transformation. During the hydrolysis, hydrophilic surface and Brönsted acid sites are favored for the adsorption of feedstock and the cleavage of glycosidic bonds. Therefore, the design and construction of cellulose-mimetic catalysts in nanopores at the molecular level is highly desired. By sulfonation of an incompletely carbonized biomass precursor, Hara's group [20-22] reported a highly active solid carbon acid. They stated that the abundant flexible polycyclic aromatic carbon sheets with $-\mathrm{SO}_{3} \mathrm{H},-\mathrm{COOH}$, and $-\mathrm{OH}$ groups endow the amorphous carbon with strong acid that capable for providing synergistic effect in catalyzing hydrolysis of cellulose. Interestingly, the surface area of the obtained carbon is only $2 \mathrm{~m}^{2} / \mathrm{g}$; the authors supposed that water and even large molecules such cellobiose can be incorporated into the carbon bulk, resulting in improved performance [21,22].

In contrast, in a different study, well-ordered, sulfonic acid-functionalized mesoporous polymers (incompletely carbonized carbonaceous materials) were employed as solid acids and exhibited promising performance in Beckmann rearrangement reactions (not in cellulose hydrolysis reactions). Wu's group [23] attributed the high activity to the efficient use of the large surface area and the mesoporous morphology. To make a fair evaluation, a systemic study was carried out on different sulfonated porous carbons, and CMK-3 (glucose origin) exhibited the best performance, with other materials ranking in the following order: OMC (ordered mesoporous carbon of resin origin) > CSAC (activated carbon of coconut origin) $>$ cell carbon (incompletely carbonized cellulose) [20-22] > MWCNT (multi-walled carbon nanotubes) > ACB (acetylene carbon black) [24]. This research revealed that both acid density and mesoporous structure are positive functions in improving the hydrolysis activity [24]. Besides acid density, Liu et al. [25] confirmed that acid strength also plays a crucial role in solid acid-catalyzed reactions. They grafted strong electron-withdrawing group of $-\mathrm{SO}_{2} \mathrm{CF}_{3}$ onto a mesoporous polymer (PDVB, which is poly(divinyl benzene)), and obtained an ultra-strong acid with a hydrophobic surface. In their study, ionic liquid was employed to dissolve the crystalline cellulose, while water was added as a reactant. This strategy elucidated the design of carbon solid acid with strong acid strength. Although considerable effort has been made to illustrate the roles that carbon and its functionalities playing in the hydrolysis process, thorough studies on how carbon structure (graphene layers, defects, basal and edge carbons) influences the sulfonation process and the subsequent catalytic performance are still very limited.

\subsection{Hydrolytic hydrogenation}

With the presence of hydrogen, hydrolytic hydrogenation of cellulose over bifunctional catalysts is highly desired because it circumvents metastable glucose and allows high selectivity to high-value chemicals or fuels at relatively high temperatures (453-523 K). This process generally involves two steps: hydrolysis of cellulose to saccharides by acid sites, and the subsequent reduction of the intermediates to polyols, including hexitol (sorbitol, mannitol, sorbitan, and isosorbide), ethylene glycol (EG), and 1,2-propylene glycol (1,2-PG) (Scheme 1). Therefore, a bifunctional catalyst that combines acid catalysis for hydrolysis and metal catalysis for hydrogenation/hydrogenolysis is required in this hydrolytic hydrogenation system.

\subsubsection{Hexitol as dominant products}


Early research invariably involved the use of mineral acids in combination with hydrogenation catalysts to proceed the hydrolytic hydrogenation process [3], until Fukuoka et al. employed supported noble metal catalysts at $463 \mathrm{~K}$ and $5 \mathrm{MPa}$ of $\mathrm{H}_{2}$ pressure without adding homogeneous acid [26]. They proposed that the hydrogen spill over on metal surface facilitated the generation of $\mathrm{H}^{+}$, which served as an acid catalyst to initiate cellulose hydrolysis. Similarly, Liu et al. applied elevated temperature (above $473 \mathrm{~K}$ ) to in situ generate $\mathrm{H}^{+}$from hot water, and achieved a better yield of hexitols over $\mathrm{Ru} / \mathrm{C}$ system (Scheme 1) [27]. Among the noble metals, $\mathrm{Ru} / \mathrm{C}$ is found most effective in transforming cellulose into $\mathrm{C}_{4}-\mathrm{C}_{6}$ sugar alcohols, for glucose and xylose are usually the main products over $\mathrm{Pt} / \mathrm{C}$ and $\mathrm{Pd} / \mathrm{C}$ due to their slow hydrogenation [28]. Later attempts to incorporate heteropoly acids in the bifunctional catalysts have been reported, while $\mathrm{Ru} / \mathrm{C}$ served as the hydrogenation component in this system. Although high yields of hexitols were achieved via this strategy (Table 1), the recovery of these soluble acid catalysts remained a critical issue [29-31]. On the other hand, solid acids were employed as acid components in recent studies to solve this problem, among which sulfonated carbon, which combines both acid function and support function in one substance, is considered one of the most desirable candidates [32,33]. In fact, not only the $-\mathrm{SO}_{3} \mathrm{H}$ groups were found to be responsible for the catalytic acid sites: as aforementioned in section 2.2, certain oxygen functionalities on carbon surface also played significant roles in the acid-catalyzed hydrolysis reaction [34-36]. With particular regard to mesoporous carbons, according to Yi et al.'s work [35] on carbon-supported Pt nanocatalysts, a very exciting result was reported in the production of hexitols from cellulose $(80 \%)$ compared with other reported solid bifunctional catalysts. They attributed the high activity to the fibrous porous structure, which enhanced the affinity of cellulose adsorption, and the mesoporosity, which induced a high selectivity to target products. However, the influence of surface chemistry and the origin of the carbons were underestimated in the
Pt-dispersion, as well as in the subsequent performance and recycle stability. Instead, thorough studies on surface functionalities and metal particle size were conducted on $s p^{2}$-dominated carbon nanotube (CNT) supports by Wang's group [34], which may shed light on the role of porous carbon playing in cellulose transformation.

Except for the function of hydrogenation, noble metals also play several other roles in the hydrolytic hydrogenation process. On one hand, the spillover effect of small particle-sized metals leads to the formation of $\mathrm{H}^{+}$from the hydrogen source, resulting in acid sites for the hydrolysis function of cellulose [33-35]. On the other hand, cationic noble metal species were found to be responsible for the transfer hydrogenation of cellulose $[37,38]$. However, the transfer hydrogenation capacity of metal particles and their subsequent catalytic activity greatly depend on the supports, although all are carbon supports but from different origins [37].

Another direction in catalyst design for cellulose transformation is to develop highly efficient non-noble metal catalysts to replace the noble ones. Conventional Ni catalysts are candidates in this reaction for hydrogenation purposes, although traditional supported Ni catalysts show low selectivity for hexitols [40]. In early exploitations, carbon-supported nickel phosphide was employed in the transformation of cellulose by Zhang's group [41], owing to its binary function: acidic sites from residual phosphate and metallic sites from crystalline nickel phosphide. With good matching of the bifunctional sites, promising performances were obtained over $16 \% \mathrm{Ni}_{2} \mathrm{P} / \mathrm{AC}$ [41], but these catalysts quickly deactivate because of the $\mathrm{P}$ leaching and Ni sintering. Subsequently, Fukuoka's group [42] unveiled phase changes of the nickel phosphide catalysts during the reaction, and attributed the high activity to the in-situ generated amorphous nickel phosphide. Besides, pretreatment of the carbon support in nitric acid can improve the stability of the nickel phosphide catalyst to a certain degree, which was explained by enhancing the interaction between the support and the catalytically active sites [42]. Meanwhile, when employing

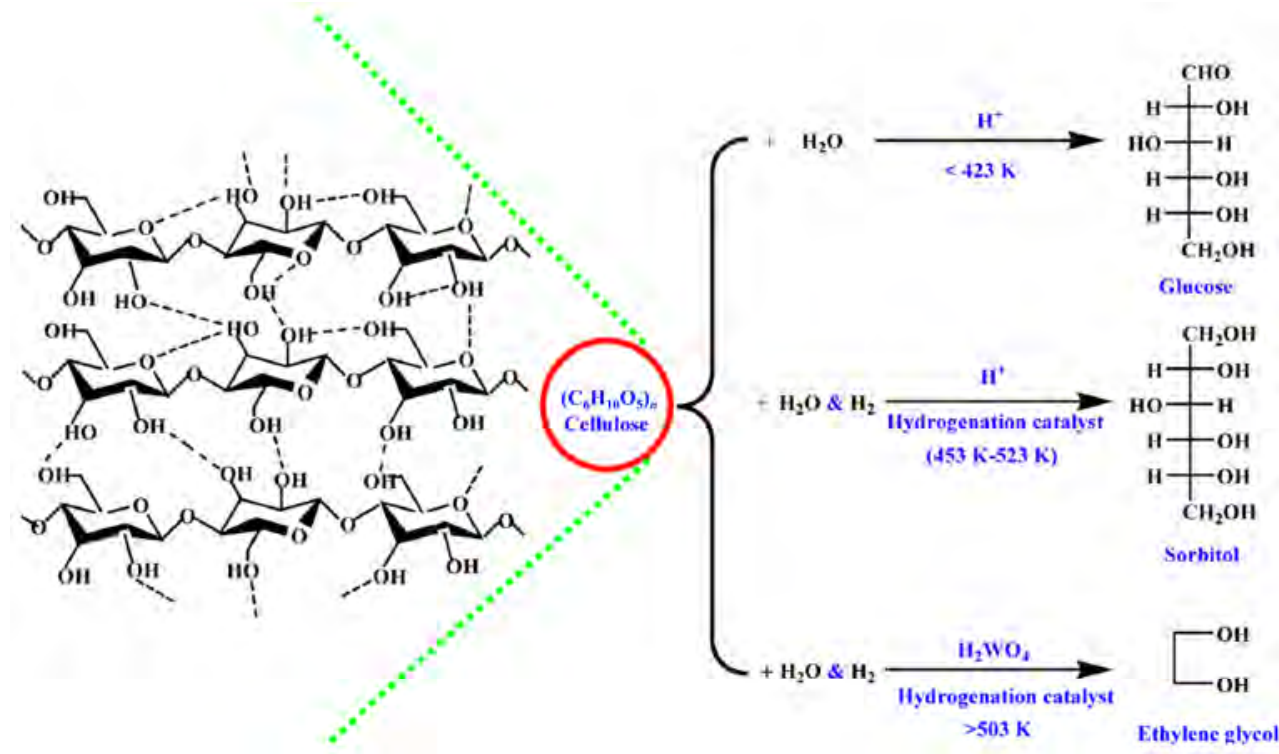

Scheme 1. Catalytic transformation routes for cellulose [4]. 
Table 1

Performance of cellulose transformation to hexitol with different catalysts.

\begin{tabular}{|c|c|c|c|c|c|c|}
\hline \multirow{2}{*}{ Catalyst } & \multicolumn{3}{|c|}{ Reaction conditions } & \multirow{2}{*}{ Yield (\%) } & \multirow{2}{*}{ Conv. (\%) } & \multirow{2}{*}{ Ref. } \\
\hline & $T / \mathrm{K}$ & $p / \mathrm{MPa}$ & $t / \mathrm{h}$ & & & \\
\hline$\overline{\mathrm{Ru} / \mathrm{C}}$ & 518 & 6 & 0.5 & 39 & 86 & {$[27]$} \\
\hline $\mathrm{Cs}_{3.5} \mathrm{SiW}+\mathrm{Ru} / \mathrm{C}$ & 443 & 5 & 48 & 90 & 100 & [29] \\
\hline $\mathrm{H}_{4} \mathrm{SiW}_{12} \mathrm{O}_{40}+\mathrm{Ru} / \mathrm{C}$ & 463 & 5 & 0.33 & 92 & 96 & {$[30]$} \\
\hline $\mathrm{H}_{3} \mathrm{PW}_{12} \mathrm{O}_{40}+\mathrm{Ru} / \mathrm{C}$ & 433 & 5 & 7 & 54 & 94 & [31] \\
\hline $\mathrm{Ru} / \mathrm{CNT}-\mathrm{C} 623-\mathrm{H} 623$ & 458 & 5 & 3 & 87 & 100 & {$[34]^{*}$} \\
\hline $\mathrm{Pt} / \mathrm{CNE}$ & 453 & 3 & 24 & 60.5 & 88.1 & [35] \\
\hline $\mathrm{Pt} / \mathrm{CNE}$ & 453 & 5 & 24 & 82.9 & 95.9 & [35] \\
\hline $\mathrm{Pt} / \mathrm{CMK}$ & 453 & 3 & 24 & 43.8 & 83.0 & [35] \\
\hline $\mathrm{Pt} / \mathrm{AC}$ & 453 & 3 & 24 & 25.8 & 80.9 & [35] \\
\hline $\mathrm{Pt} / \mathrm{MWCNT}$ & 453 & 3 & 24 & 11.6 & 70.6 & [35] \\
\hline $\mathrm{Pt} / \mathrm{CNT}$ & 453 & 3 & 24 & 4.3 & 77.5 & {$[35]$} \\
\hline $\mathrm{Pt} / \mathrm{GO}$ & 453 & 3 & 24 & 7.2 & 100 & [35] \\
\hline $\mathrm{Ru} / \mathrm{AC}($ Norit) & 463 & 2-propanol & 18 & 42.5 & 74.4 & {$[37]$} \\
\hline $\mathrm{Ru} / \mathrm{CMK}-3$ & 463 & 2-propanol & 18 & 45.0 & 81.2 & [37] \\
\hline $\mathrm{Ru} / \mathrm{C}-\mathrm{Q} 10$ & 463 & 2-propanol & 18 & 45.8 & 80.2 & {$[37]$} \\
\hline $20 \% \mathrm{Ni} / \mathrm{AC}$ & 518 & 6 & 0.5 & 19.7 & 61.9 & {$[40]$} \\
\hline $20 \% \mathrm{Ni} / \mathrm{MC}$ & 518 & 6 & 0.5 & 42.1 & 84.5 & [40] \\
\hline $16 \% \mathrm{Ni}_{2} \mathrm{P} / \mathrm{AC}(1: 2)$ & 498 & 6 & 1.5 & 48.4 & 100 & {$[41]$} \\
\hline $10 \mathrm{Ni} 2.6 \mathrm{P} / \mathrm{C}$ & 503 & 5 & 0.67 & 66.5 & 91.9 & {$[42]$} \\
\hline $10 \mathrm{Ni} 2.6 \mathrm{P} / \mathrm{C}-\mathrm{m}$ & 503 & 5 & 0.67 & 56 & 86.9 & {$[42]$} \\
\hline 10Ni2.6P/C-modified-recyle-1 & 503 & 5 & 0.67 & 63.5 & 97 & {$[42]$} \\
\hline 10Ni2.6P/C-modified-recyle-2 & 503 & 5 & 0.67 & 42.4 & 91.4 & {$[42]$} \\
\hline $\mathrm{Ni}(50) / \mathrm{KB}$ & 483 & 5 & 6 & 64 & 90 & {$[43]$} \\
\hline $\mathrm{Ni}(70) / \mathrm{KB}$ & 483 & 5 & 6 & 59 & 87 & [43] \\
\hline $\mathrm{Ni}(70) /$ KB-recyle-5 & 483 & 5 & 6 & 64 & - & [43] \\
\hline $\mathrm{Ni}(70) /$ KB-recyle-7 & 483 & 5 & 6 & 56 & - & [43] \\
\hline Ni(70)/KB-recyle-9 & 483 & 5 & 6 & 42 & - & [43] \\
\hline $3.0 \% \mathrm{Ni} / \mathrm{CNF}$ & 463 & 6 & 24 & 56.5 & 92.2 & {$[44]$} \\
\hline 3.0\% Ni/CNF-recyle-3 & 463 & 6 & 24 & 53.9 & 94.0 & {$[44]$} \\
\hline $7.5 \% \mathrm{Ni} / \mathrm{CNF}$ & 463 & 6 & 24 & 76 & 93 & {$[45]$} \\
\hline
\end{tabular}

* The main product was sorbitol.

mesoporous carbon as the support, $\mathrm{Ni}$ catalysts were also found highly active in the first two cycles, but deactivated within the third use [40]. Recently, by increasing the loading of $\mathrm{Ni}$, fairly durable and active $\mathrm{Ni}$ catalysts have been prepared by Fukuoka's group [43], and the high Ni loading is proposed key to the superior stability, for larger crystalline $\mathrm{Ni}$ is more resistant to sintering and surface oxidation. According to these results, the loading of $\mathrm{Ni}$ and its interaction with carbon, as well as the structure and surface functionalities of the supports, are all found to be crucial factors in determining the catalytic performance. On the other hand, carbon nanofiber (CNF)-supported Ni catalysts were employed by Sels's group [44] to improve the accessibility of cellulose to the active sites; they proposed that the large amount of (111) plane of Ni might be responsible for the high activity. Moreover, proper balances of the acidic/metallic sites were also confirmed beneficial to high activity and hexitol selectivity in their follow-up study [45]. However, since Ni (111) is the most stable plane and commonly exists, it is still lack of solid evidence to claim that $\mathrm{Ni}$ (111) is the sole reason for the high activity. Moreover, the fact that the low $\mathrm{Ni}$ loading $\mathrm{Ni} / \mathrm{CNF}$ catalyst exhibited promising stability after three cycles [44] was inconsistent with Fukuoka's attitude that higher $\mathrm{Ni}$ is the key to better stability [43]. Therefore, the genuine active site of $\mathrm{Ni}$, the real reason for the activity differences, as well as the key for catalysts durability, is still unclear and controversial.

\subsubsection{EG as the dominant product}

When EG is the dominant product of cellulose transformation, three steps are involved: (1) hydrolysis of the cellulose; (2) cleavage of the $\mathrm{C}-\mathrm{C}$ bond; and (3) hydrogenation of the glycolaldehyde. Compared with the hexitol-favored route, an additional cleavage of $\mathrm{C}-\mathrm{C}$ bond is required to obtain $\mathrm{EG}$, and tungsten species were confirmed playing crucial roles in this procedure. Fortunately, our group has developed a series of efficient $\mathrm{W}$-based catalysts and unearthed the role $\mathrm{W}$ playing, which in turn allowed mechanistic insight into catalysts design for superior activity and selectivity in catalytic cellulose trans-

Table 2

Performance of cellulose transformation to EG with W-containing catalysts.

\begin{tabular}{lcccccc}
\hline \multirow{2}{*}{ Catalyst } & \multicolumn{7}{c}{ Reaction conditions } & Yield & Conv. & \multirow{2}{*}{ Ref. } \\
\cline { 2 - 6 } & $T / \mathrm{K}$ & $p / \mathrm{MPa}$ & $t / \mathrm{h}$ & $(\%)$ & $(\%)$ & \\
\hline $\mathrm{W}_{2} \mathrm{C} / \mathrm{AC}$ & 518 & 6 & 0.5 & 27.3 & 98 & {$[47]$} \\
$\mathrm{Ni}-\mathrm{W}_{2} \mathrm{C} / \mathrm{AC}$ & 518 & 6 & 0.5 & 61 & 100 & {$[47]$} \\
$\mathrm{WC}_{x} / \mathrm{MC}$ & 518 & 6 & 0.5 & 72.9 & 100 & {$[48]$} \\
$\mathrm{Ni}-\mathrm{WC}_{x} / \mathrm{MC}$ & 518 & 6 & 0.5 & 74.4 & 100 & {$[48]$} \\
$\mathrm{Ru} / \mathrm{C}+\mathrm{H}_{2} \mathrm{WO}_{4}$ & 518 & 6 & 0.5 & 58.5 & 100 & {$[49]$} \\
$\mathrm{Ru} / \mathrm{C}+\mathrm{WO}_{3}$ & 518 & 6 & 0.5 & 48.9 & 100 & {$[50]$} \\
$\mathrm{Ru} / \mathrm{C}+50 \% \mathrm{WO}_{2} / \mathrm{Al}_{2} \mathrm{O}_{3}+\mathrm{C}_{\text {act }}$ & 518 & 6 & 0.5 & 30.7 & 100 & {$[50]^{*}$} \\
$\mathrm{Ru} / \mathrm{C}+\mathrm{WO}_{3}$ & 478 & 6 & 0.5 & 12.1 & 23.4 & {$[50]$} \\
$\mathrm{Ru} / \mathrm{C}+\mathrm{WO}_{3}+\mathrm{C}_{\text {act }}$ & 478 & 6 & 0.5 & 7.3 & 22.8 & {$[50]^{*}$} \\
\hline
\end{tabular}

* The main product was $\mathrm{PG}$. 
formation $[2,4]$. For the sake of brevity and cohesion, here we opt to highlight the function of porous carbon (as shown in Table 2), instead of covering a large number of references focusing on $\mathrm{W}$ species that are already included in the published reviews $[2,4]$.

In many reactions, carbides share similar catalytic properties with noble metal catalysts due to the insertion of $\mathrm{C}$ atom into the lattice of the parent metals, which leads to an alike $\mathrm{d}$ electron density as noble metal catalysts [46]. Impregnating W species on carbon support followed by reduction under certain condition can obtain carbon supported tungsten carbide catalysts, and tungsten carbide catalyzes not only the cleavage of $\mathrm{C}-\mathrm{C}$ bonds, but also the hydrogenation. Therefore, the cascade reaction can occur over one catalyst, $\mathrm{WC}_{x} / \mathrm{C}$, with a promising selectivity towards EG [47]. Meanwhile, adding a hydrogenation component $\left(\mathrm{Ni}, \mathrm{Ru}\right.$, etc.) to $\mathrm{WC}_{x} / \mathrm{C}$ greatly increases the yield of EG by decreasing the unsaturated byproducts. The promotional effect lies in the compensation of the insufficient hydrogenation capacity of $\mathrm{WC}_{x} / \mathrm{C}$ [47]. Interestingly, limited by the interconnected mesopores, $\mathrm{WC}_{X}$ is highly dispersed on mesoporous carbon (MC), and achieves a superior EG yield compared with $\mathrm{WC}_{x} / \mathrm{C}$ without the addition of $\mathrm{Ni}$ [48]. The 3D mesoporous structure, on one hand, improved the dispersion and accessibility of the active component $\mathrm{WC}_{x}$, on the other hand, facilitated the transportation of large molecules, and thereby enhanced the hydrogenation activity of $\mathrm{WC}_{x}$. When the hydrogenation capacity of $\mathrm{WC}_{x}$ is sufficient, the promotion effect of $\mathrm{Ni}$ is supposed to be negligible, which corroborates the results obtained over $\mathrm{Ni}^{-} \mathrm{WC}_{x} / \mathrm{MC}$ [48].

Although carbon supports are preferred in the cellulose transformation due to its inertness and excellent hydrothermal stability, the active sites, tungsten carbide, are subject to oxidation even upon exposure to the ambient atmosphere. This results in the deactivation of hydrogenation function after several cycles due to the collective effect of oxidation. To overcome this problem, a combination of tungsten species and $\mathrm{Ru} / \mathrm{C}$ (noble metal catalyst) was employed in later studies [49,50], and high stability without compromising the activity and the selectivity towards EG was achieved [49]. Upon the addition of activated carbon to this system, the cellulose conversion essentially remained, but the main products, surprisingly, changed to propylene glycol (PG) from EG. Liu et al. [50] attributed this to the surface basicity of the added activated carbon, which was stated to accelerate the isomerization of glucose into fructose, and hence led to the dominant formation of PG.

\subsection{Modified porous carbon in cellulose transformation}

\subsubsection{Heteroatom-modified carbon}

Similar to oxygen-containing functionalities, other heteroatoms (N, S, P, B, etc.) also define the functional groups on the carbon surface, and the study of their role in manipulating the surface chemistry has increased considerably in recent years. Essentially, nitrogen can be introduced to carbons in two ways: either by carbonizing nitrogen-containing organic compounds or by treatment of carbon materials at high temperatures with nitrogen-containing gases [51]. Generally, the interaction with the nitrogen-containing functional groups promotes the catalytic activity of the metal [52], not only because the metal nanoparticles are very stable and uniform on the nitrogen-modified carbon supports, but also because there are electronic interactions and electron transfers between the metal and the nitrogen-modified carbon supports. Wang's group [53] synthesized nitrogen-doped mesoporous carbon $\left(\mathrm{CN}_{x}\right)$ by using a nitrogen-containing ionic liquid, and then loaded Pd nanoparticles onto $\mathrm{CN}_{x}$ (Pd@CN $\mathrm{CN}_{0.132}$ ), which exhibits high activity for the hydrodeoxygenation of vanillin, a common component in lignin-derived bio-oil [53]. So far there is no example of heteroatom-modified carbons for cellulose transformation; however, undoubtedly such heteroatom-modified carbons will soon find their applications in cellulose conversion.

\subsubsection{Mesoporous carbon composite}

The degradation of cellulose in water requires harsh conditions (i.e., the reaction temperature needs to be between 100 and $300{ }^{\circ} \mathrm{C}$ ), whereas conventional metal oxide catalyst supports designed for gas-phase reactions are not suitable under these hydrothermal conditions. For example, $\gamma-\mathrm{Al}_{2} \mathrm{O}_{3}$ is transformed into boehmite $(\mathrm{AlOOH})$ in hot water with significantly decreased acidity and surface area [54], and the catalytic performance is reduced in reuse experiments [55]. Likewise, SBA-15, a type of ordered mesoporous silica, suffers from collapse of the well-ordered structure when heated to $200{ }^{\circ} \mathrm{C}$ in water, and loses $96 \%$ of its surface area [56]. One approach to overcome this shortage is to use mesoporous carbon-metal oxide composites instead of metal oxides for the conversion of cellulose. Mesoporous carbon-metal oxide composites can be synthesized in three ways. The first method involves the deposition of a thin carbon film on the surface of the metal oxide [56]; the second method is by supporting the metal oxide with carbon [57]; and the third method begins with the synthesis of a composite composed of a carbon precursor and a metal oxide sol [58].

Mesoporous carbon-metal oxide composites are far more stable than the corresponding metal oxide support under the same hydrothermal conditions. When the composite of carbon-coated alumina is subjected to liquid water at $200{ }^{\circ} \mathrm{C}$ for several hours, the alumina remains as $\gamma-\mathrm{Al}_{2} \mathrm{O}_{3}$ after hydrothermal treatment [56]. In addition, the carbon part of the composites can be functionalized with acid groups (e.g., $\mathrm{SO}_{3} \mathrm{H}$ and $\mathrm{COOH}$ ); their metal oxide components also provide good mechanical stability, and the hybrid surface structure comprises metal oxide and carbon components, facilitating the adsorption of $\beta$-1,4-glucan [33]. Furthermore, the strength of the metal-support interaction can be adjusted by using the carbon-metal oxide composites, which plays a critical role in the activity of the catalysts [58].

\section{Conclusion and prospects}

In general, hierarchical structures bearing mesopores are favored for mass transfer and reactant diffusion, while hydrophilic surfaces, in particular bearing carboxylic and phenolic functionalities, are favored for the adsorption of $\beta$-1,4-glucan in 
the feedstock, and can provide acid sites for hydrolysis. If more and/or stronger acid sites are desired/required, extra treatments are necessary to fulfill the request for solid acid or bifunctional catalysts. In some cases, carbon supports with basic sites were also reported responsible for accelerating the isomerization of glucose and hence can change the product selectivity. Meanwhile, when employing mesoporous carbons as the supports or catalysts, researchers should be very careful when drawing conclusions about the function of structures without considering the surface properties, for the method to remove the structure templates can also be regarded as a pretreatment of the carbon materials, therefore the surface chemistry change should also be considered.

In general, since the renewed upsurge in studies on biomass conversion at the beginning of this century, great progresses have been made in the one-pot conversion of cellulose over carbon and/or carbon-supported catalysts. However, (1) most researches are focused on the metallic active sites, the role played by carbon supports, especially the surface chemistry and the hybridization of carbon, has rarely been investigated; (2) although mesoporous and hierarchical-structured carbons are preliminarily testified beneficial for cellulose transformation, the preparation of these supports are time- and cost-consuming, hence facile and energy-efficient strategies to fabricate specifically structured carbons are desirable; (3) from a commercial point of view, efficient reaction process, low energy-consumption separation system, and valuable utilization of byproducts are necessary; (4) since fossil crude oils are still available in large quantities, the production of fuels from biomass is still, and will not be, cost-competitive in the near future, thus transformation of cellulose directly into specially functionalized materials or high value-added materials is another profitable but challenging issue.

\section{Acknowledgments}

The authors gratefully acknowledge Mingyuan Zheng, Jifeng Pang and Junying Zhang for fruitful discussion.

\section{References}

[1] Melero J A, Iglesias J, Garcia A. Energy \& Environ Sci, 2012, 5: 7393

[2] Zheng M, Pang J, Wang A, Zhang T. Chin J Catal (郑明远, 庞纪峰, 王 爱琴, 张涛. 催化学报), 2014, 35: 602

[3] Huber G W, Iborra S, Corma A. Chem Rev, 2006, 106: 4044

[4] Wang A Q, Zhang T. Acc Chem Res, 2013, 46: 1377

[5] Fukuoka A, Dhepe P L. Chem Record, 2009, 9: 224

[6] Mäki-Arvela P, Holmbom B, Salmi T, Murzin D Y. Catal Rev-Sci Eng, 2007, 49: 197

[7] Mäki-Arvela P, Salmi T, Holmbom B, Willför S, Murzin D Y. Chem Rev, 2011, 111: 5638

[8] Zakzeski J, Bruijnincx P C A, Jongerius A L, Weckhuysen B M. Chem Rev, 2010, 110: 3552

[9] Besson M, Gallezot P, Pinel C. Chem Rev, 2014, 114: 1827

[10] Dutta S. RSC Adv, 2012, 2: 12575

[11] Lin K F, Pescarmona P P, Houthoofd K, Liang D D, Van Tendeloo G, Jacobs P A.J Catal, 2009, 263: 75

[12] De Cremer G, Roeffaers M B J, Bartholomeeusen E, Lin K F, Dedecker P, Pescarmona P P, Jacobs P A, De Vos D E, Hofkens J, Sels B F. Angew Chem Int Ed, 2010, 49: 908

[13] Rodŕíguez-Reinoso F, Seṕulveda-Escribano A. Carbon as Catalyst Support. John Wiley \& Sons Inc, 2008. 131

[14] Liang C D, Li Z J, Dai S. Angew Chem Int Ed, 2008, 47: 3696

[15] Zhao X C, Zhang Q, Chen C M, Zhang B S, Reiche S, Wang A Q, Zhang T, Schlögl R, Su D S. Nano Energy, 2012, 1: 624

[16] Zhao X C, Wang A Q, Yan J W, Sun G Q, Sun L X, Zhang T. Chem Mater, 2010, 22: 5463

[17] Marsh H, Rodríguez-Reinoso F. Activated Carbon, Oxford: Elsevier Science, 2006. 87

[18] Verboekend D, Perez-Ramirez J. Catal Sci Technol, 2011, 1: 879

[19] Yamaguchi D, Kitano M, Suganuma S, Nakajima K, Kato H, Hara M. JPhys Chem C, 2009, 113: 3181

[20] Toda M, Takagaki A, Okamura M, Kondo J N, Hayashi S, Domen K, Hara M. Nature, 2005, 438: 178

[21] Suganuma S, Nakajima K, Kitano M, Yamaguchi D, Kato H, Hayashi S, Hara M. J Am Chem Soc, 2008, 130: 12787

[22] Okamura M, Takagaki A, Toda M, Kondo J N, Domen K, Tatsumi T, Hara M, Hayashi S. Chem Mater, 2006, 18: 3039

[23] Xing R, Liu N, Liu Y M, Wu H H, Jiang Y W, Chen L, He M Y, Wu P. Adv Funct Mater, 2007, 17: 2455

\section{Graphical Abstract}

Chin. J. Catal., 2015, 36: 1419-1427 doi: 10.1016/S1872-2067(15)60942-1

\section{Porous carbon in catalytic transformation of cellulose \\ Xiaochen Zhao, Jinming Xu, Aiqin Wang, Tao Zhang * \\ Dalian Institute of Chemical Physics, Chinese Academy of Sciences}

Porous carbon in catalytic cellulose transformation is reviewed in terms of the properties of carbon, carbon as solid acid in cellulose hydrolysis, and carbon as catalyst support in cellulose hydrolytic hydrogenation reaction.

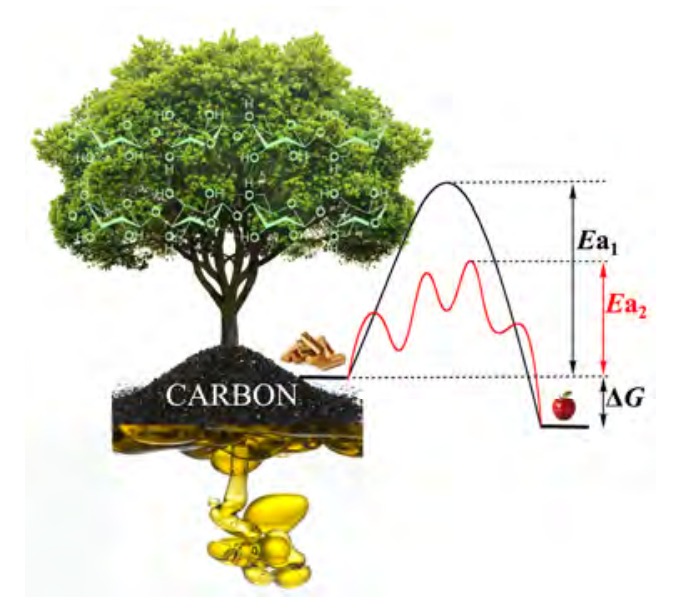


[24] Pang J F, Wang A Q Zheng M Y, Zhang T. Chem Commun, 2010, 46: 6935

[25] Liu F J, Zheng A M, Noshadi I, Xiao F S. Appl Catal B, 2013, 136-137: 193

[26] Fukuoka A, Dhepe P L. Angew Chem Int Ed, 2006, 45: 5161

[27] Luo C, Wang S, Liu H. Angew Chem Int Ed, 2007, 46: 7636

[28] Palkovits R, Tajvidi K, Procelewska J, Rinaldi R, Ruppert A. Green Chem, 2010, 12: 972

[29] Geboers J, Van de Vyver S, Carpentier K, Jacobs P, Sels B. Green Chem, 2011, 13: 2167

[30] Geboers J, Van de Vyver S, Carpentier K, de Blochouse K, Jacobs P Sels B. Chem Commun, 2010, 46: 3577

[31] Palkovits R, Tajvidi K, Ruppert A M, Procelewska J. Chem Commun, 2011, 47: 576

[32] Kobayashi H, Komanoya T, Hara K, Fukuoka A. ChemSusChem 2010, 3: 440

[33] Van de Vyver S, Peng L, Geboers J, Schepers H, de Clippel F, Gommes C J, Goderis B, Jacobs P A, Sels B F. Green Chem, 2010, 12 : 1560

[34] Deng W P, Liu M, Tan X S, Zhang Q H, Wang Y. J Catal, 2010, 271 22

[35] Park D S, Yun D, Kim T Y, Baek J, Yun Y S, Yi J. ChemSusChem, 2013, 6: 2281

[36] Zhao X C, Wang J, Chen C M, Huang Y Q, Wang A Q, Zhang T. Chem Commun, 2014, 50: 3439

[37] Kobayashi H, Matsuhashi H, Komanoya T, Hara K, Fukuoka A. Chem Commun, 2011, 47: 2366

[38] Park H J, Kim H D, Kim T W, Jeong K E, Chae H J, Jeong S Y, Chung Y M, Park Y K, Kim C U. ChemSusChem, 2012, 5: 629

[39] Shrotri A, Kobayashi H, Tanksale A, Fukuoka A, Beltramini J. ChemCatChem, 2014, 6: 1349

[40] Pang J F, Wang A Q, Zheng M Y, Zhang Y H, Huang Y Q, Chen X W, Zhang T. Green Chem, 2012, 14: 614
[41] Ding L N, Wang A Q, Zheng M Y, Zhang T. ChemSusChem, 2010, 3: 818

[42] Yang P F, Kobayashi H, Hara K, Fukuoka A. ChemSusChem, 2012, 5: 920

[43] Kobayashi H, Hosaka Y, Hara K, Feng B, Hirosaki Y, Fukuoka A. Green Chem, 2014, 16: 637

[44] Van de Vyver S, Geboers J, Dusselier M, Schepers H, Vosch T, Zhang L, Van Tendeloo G, Jacobs P A, Sels B F. ChemSusChem, 2010, 3: 698

[45] Van de Vyver S, Geboers J, Schutyser W, Dusselier M, Eloy P, Dornez E, Seo J W, Courtin C M, Gaigneaux E M, Jacobs P A, Sels B F. ChemSusChem, 2012, 5: 1549

[46] Chen J G G. Chem Rev, 1996, 96: 1477

[47] Ji N, Zhang T, Zheng M Y, Wang A Q, Wang H, Wang X D, Chen J G A. Angew Chem Int Ed, 2008, 47: 8510

[48] Zhang Y H, Wang A Q Zhang T. Chem Commun, 2010, 46: 862

[49] Tai Z J, Zhang J Y, Wang A Q, Zheng M Y, Zhang T. Chem Commun, 2012, 48: 7052

[50] Liu Y, Luo C, Liu H C. Angew Chem Int Ed, 2012, 51: 3249

[51] Xu J M, Zhao X C, Wang A Q Zhang T. Carbon, 2014, 80: 610

[52] Liang H W, Wei W, Wu Z S, Feng X L, Müllen K. J Am Chem Soc, 2013, 135: 16002

[53] Xu X, Li Y, Gong Y T, Zhang P F, Li H R, Wang Y. J Am Chem Soc, 2012, 134: 16987

[54] Ravenelle R M, Copeland J R, Kim W G, Crittenden J C, Sievers C. ACS Catal, 2011, 1: 552

[55] Kobayashi H, Ito Y, Komanoya T, Hosaka Y, Dhepe P L, Kasai K, Hara K, Fukuoka A. Green Chem, 2011, 13: 326

[56] Pham H N, Anderson A E, Johnson R L, Schmidt-Rohr K, Datye A K. Angew Chem Int Ed, 2012, 51: 13163

[57] Wu Z X, Li W, Webley P A, Zhao D Y. Adv Mater, 2012, 24: 485

[58] Xu J M, Wang A Q, Wang X D, Su D S, Zhang T. Nano Res, 2011, 4: 50

\title{
多孔炭材料在纤维素催化转化中的应用
}

\author{
赵晓晨，徐金铭，王爱琴，张 涛* \\ 中国科学院大连化学物理研究所, 催化基础国家重点实验室, 辽宁大连116023
}

摘要: 生物质作为自然界唯一可再生的有机碳资源, 其利用受到了越来越多的关注. 特别是随着能源和环境危机的日益加重, 将 生物质中非可食用部分催化转化为燃料及具有高附加值的化学品被认为是高效、环保、原子经济的绿色过程. 同时, 多孔炭材料 具有丰富的孔道结构、优异的水热稳定性和大比表面积, 是生物质催化转化反应中最常用的载体材料之一. 兼之炭材料表面极 性、亲疏水性的可调变性, 及对酸碱溶剂的反应惰性, 也使其无论在学术研究还是在工业应用中都具有特殊的优势. 另外, 随着纳 米炭材料科学的飞速发展, 合成孔径、形貌、及表面官能团可控的介孔炭和具有多级孔道结构的多孔炭材料成为可能, 将其应用 到纤维素催化转化过程中, 对深入理解孔道结构、表面官能团对纤维素转化的作用, 揭示催化反应作用机制, 指导炭基催化剂的设 计合成, 均具有重要意义.

在本综述中, 我们首先对纤维素转化中多孔炭的孔道结构和表面官能团性质的独特作用进行了阐述. 由于商业活性炭的孔 径一般在微孔尺度, 但纤维素及可溶低聚糖的分子体积较大, 因而其在活性炭中的传质受到了极大的限制. 通过模板法获得的介 孔炭材料, 可实现孔径在 $2-10 \mathrm{~nm}$ 的可控合成, 大大提高了反应物的扩散速率, 使之能与催化活性位有效接触. 但孔道过于狭长, 在反应过程中堵塞的可能性增高, 进而导致催化剂失活; 因此, 在介孔孔道的基础上, 建立互通的多级孔道结构对反应物、中间 物、和产物的扩散, 及催化活性的保持更为有利. 另一方面, 炭材料表面的含氧官能团不仅具有加强1,4-糖苗键吸附的作用, 还可 以作为酸性活性中心催化水解反应的进行; 尤其是在传统的水相纤维素催化转化过程中, 亲水表面对多孔炭催化剂与反应物的 接触非常有利.

本文以纤维素水解及纤维素水解加氢反应为例, 展开讨论了多孔炭作为固体酸及双功能催化剂载体的应用. 在水解反应中, 纤维素首先在热水中降解为可溶低聚糖, 之后再与活性炭表面官能团反应; 其中多孔炭的比表面积、酸量、及酸强度均是促进水 解发生的正向因素. 在水解加氢反应中, 炭载贵金属催化剂作为最常用的加氢催化剂, 可获得以六元醇为主的纤维素转化产物. 除了加氢作用之外, 贵金属小颗粒被证实可以通过氢溢流作用提供水解所需的 $\mathrm{H}^{+}$, 同时, 正价的贵金属也可促进反应过程中的氢 
转移. 另一方面, 由于铇物种可催化逆羟醛缩合反应的发生, 因此在反应体系中引入铇物种时, 水解加氢的主要产物由六元醇变 为乙二醇. 需要特别指出的是, 在纤维素催化水解加氢的过程中, 多孔炭材料作为载体同样具有非常重要的作用: 一方面, 三维介 孔的孔道结构不仅有利于反应物、产物的扩散, 也有利于加氢金属催化剂的分散, 进而提高金属的催化加氢能力; 另一方面, 当炭 材料的表面化学性质改变时, 也会影响产物的选择性分布, 例如当炭表面显碱性时, 由于异构化作用, 丙二醇成为主要产物.

本文最后, 我们列举了一些新型多孔炭材料, 包括杂原子改性的多孔炭材料和金属氧化物-炭复合多孔材料的合成方法及其 在纤维素催化转化乃至生物质转化中的潜在应用.

关键词: 生物质转化; 催化; 多孔炭; 活性炭; 介孔炭; 纤维素

收稿日期: 2015-05-29. 接受日期: 2015-06-28. 出版日期: 2015-09-20.

*通讯联系人. 电话: (0411)84379015; 传真: (0411)84685940; 电子信箱: taozhang@dicp.ac.cn

基金来源：国家自然科学基金(21303187, 21403218, 21176235).

本文的英文电子版由Elsevier出版社在ScienceDirect上出版(http://www.sciencedirect.com/science/journal/18722067). 